Maktūbāt va bayānāt-e siyāsī va ejtemā'î̀-e 'olamāye šìe, 1200-1323. Jeld-e avval, Tehrān, Ney, 1384/2005, $472 \mathrm{p}$.

\title{
Denis Hermann
}

\section{(2) OpenEdition}

Journals

Édition électronique

URL : http://journals.openedition.org/abstractairanica/18001

DOI : 10.4000/abstractairanica. 18001

ISSN : 1961-960X

Éditeur :

CNRS (UMR 7528 Mondes iraniens et indiens), Éditions de l'IFRI

\section{Édition imprimée}

Date de publication : 15 mai 2007

ISSN : 0240-8910

Référence électronique

Denis Hermann, « Maktūbāt va bayānāt-e siyāsī va ejtemāîe 'olamā-ye šîe, 1200-1323. Jeld-e avval, Tehrān, Ney, 1384/2005, 472 p. », Abstracta Iranica [En ligne], Volume 28 | 2007, document 193, mis en ligne le 18 septembre 2007, consulté le 25 septembre 2020. URL : http://journals.openedition.org/ abstractairanica/18001 ; DOI : https://doi.org/10.4000/abstractairanica.18001

Ce document a été généré automatiquement le 25 septembre 2020

Tous droits réservés 


\title{
Maktūbāt va bayānāt-e siyāsī va ejtemā'ì-e 'olamā-ye šì'e, 1200-1323. Jeld-e avval, Tehrān, Ney, 1384/2005, $472 \mathrm{p}$.
}

\author{
Denis Hermann
}

Ce travail d'édition de sources vient enrichir très utilement les documents à disponibilité des chercheurs pour l'étude du rôle politique et social des 'olamā shi'ites dans l'Iran qajar. 104 décrets (hokm), fatvā, télégrammes, traités, pamphlets ou encore poèmes politiques sont édités chronologiquement. Ceux-ci s'étendent de l'arrivée au pouvoir de Āqā Mohammad Hāān Qājār en 1200/1785-86 à l'aube du mouvement constitutionnaliste. Un sujet est largement prédominant : la peur de l'accroissement de la pression occidentale sur l'Iran et la perte du caractère islamique de la nation. La majorité des documents sont en langue persane. Les autres, originellement rédigés en arabe, sont tous traduits en persan. Chacun des 104 documents est accompagné de quatre informations élémentaires : 1) le nom de son auteur ;2) une indication sur le contenu ; 3) la date à laquelle il fut rédigé ; 4) la langue d'origine du document. A la fin de l'ouvrage, le lecteur trouvera une courte mais très utile bibliographie sur chaque auteur de document ainsi qu'un index des noms, des sources et des lieux. Nous espérons que le prochain volume prévu, et qui devrait concerner la période du mouvement constitutionnel, sera rapidement publié. 
INDEX

Thèmes : 4.2.1. Safavides et Qâjârs

\section{AUTEURS}

DENIS HERMANN

IFRI - Téhéran 